\title{
Sale of the Crown of Beer: A Study Based on the Strategy Tripod of Mike Peng
}

\author{
José G.Vargas-Hernandez \\ M. B. A. Ph.D \\ Noé René Luna Plascencia \\ University Center for Economic and Managerial Sciences \\ University of Guadalajara
}

Tel: 523-337-703-340 ext. 25685

E-msil: reno_nlp@hotmail.com; jvargas2006@gmail.com; jgvh0811@yahoo.com

Received: June 13, $2015 \quad$ Accepted: October 30, $2015 \quad$ Published: November 20, 2015

doi:10.5296/wjbm.v1i2.8660ＵRL: http://dx.doi.org/10.5296/wjbm.v1i2.8660

\begin{abstract}
The main objective of this study is to analyze through tripod strategy Peng, the basics of why the acquisition and sale of Grupo Modelo (which it is the largest brewer in Mexico with the highest market share) through analysis of the annual reports of the company. The analysis will be supported under three main theories: theory of industry, theory of resources and capabilities and ultimately theory of institutions. The paper concludes with a compilation and analysis of information giving rise to answer the question why Grupo Modelo sold? And if have you had a positive result in the acquisition of Grupo Modelo by the company ABI?
\end{abstract}

Keywords: Acquisitions, Institutions, Industry, Strategies, Resources 


\section{Introduction}

Companies have a main objective that is to make profits, which are reflected in earnings. So, some companies that have profits cannot be limited in their growth and carry out the diversification of products to stay on the market (Peng, 2010). This diversification leads to generating value and permanence in the same or improve their market position (Tournois, 2014). Another important point is the internationalization of the company through exporting its products reaching other countries which may be homogeneous or heterogeneous in their country of origin. The above points are important for the value of the firm and this makes set eyes on this.

Market concentration is an essential part of potential acquisitions as companies contain a significant part of the quota which can be acquired through the acquisition. This works as guarantee to the acquiring company. A very important point is this based on the theory of resources and capabilities, which mentions the value, rarity, difficult imitation and how the company organizes these points that are nodal for a diamond in the industry where the firm is developed (Peng, 2010). These points will be analyzed thoroughly for Grupo Modelo is a diamond in the industry.

Institutions are those imposing the rules (North, 1990), and these will give guidance. They do not work as a referee but as a creator of rules that make the game viable or not of companies in the environment. On the other hand, it can set rules that disadvantage other competitors, for example on entries to markets of certain countries through high taxes and tariffs or other regulations. At this point it is seen how institutions have prevented the entry of other competitors in the beer industry. Finally a conclusion is made by taking into account all the evidence obtained and analyzed through theories of the tripod strategy of Peng (2010).

\section{Hypothesis}

Market conditions are the factors that led to the acquisition of Grupo Modelo, but have produced a positive result in the securities of the company ABI.

\section{Theoretical Framework}

Companies seek to maximize their profits by restricting their resources (Varian, 2005). This assumption makes the companies seekers of the most possible profits. This goal of highest profits can be achieved in several ways. One of them is the corporate strategy, which is understood as the way the company creates value through the configuration and coordination of their activities in multiple markets (Peng, 2010, p. 256). Entering new markets can bring higher profits and stay within the target market.

Another important point for this permanence is diversification, which consists of increasing the company's business with homogeneous activities that already has. Diversification can be divided into two types: Product diversification and geographic diversification. Diversification by product is understood that the firm enters to different industries and by geographic diversification the firm enters to other countries (Peng, 2010).

The diversification of products can be divided into: 
A. Diversification of related products is made when diversification of products of both brands to combine resources and thus have lower costs plus the combination of technology, and market related capabilities.

B. Diversification of unrelated products. These product diversifications are not related to the main production company (Peng, 2010). These products can identify markets which are expanding and have not been exploited.

There is evidence supported by several studies that indicate the positive relationship between the diversification of products (Peng, 2010). This positive relationship leads to think about how valuable the companies that have diversified products on the market are.

There are two types of geographical diversification, called limited and extensive international scope and reach. Limited scope is based on diversification to countries where culture is homogeneous and extensive scope that takes a global reach (Peng, 2010). Evidence suggests that the more scope the firm, higher yields obtain which means that the positive relationship between yields and until which countries has presence the company. But growth cannot be taken in a consistent manner. It can only be given to a certain extent, and it cannot always give the best remarks between globalized better (Peng, 2010).

Based on the diversification of related products and the scope to which a company may have, it can be done a classification of companies where the company may be a company with diversified products and have a long reach. But they can also be other companies with limited scope and diversification of products (Peng, 2010).

Considerations based on the tripod of Peng strategy can give a broader scenario analysis. On considerations based on industry, it is mentioned that there are motivations for product diversification and geographical diversification. One of which is the growth of the industry where it is judged whether the industry is growing, is static or in decline, or is needed incentives to enter the growing industry. Another motivation is the rivalry between firms; the advantage can be taken for product diversification or cost advantage. When barriers to entry exist very marked, the best for an incoming company is acquiring (Peng, 2010; Porter, 1980). Entry barriers may result from a rise in investment or technology; this can create monopolies (Varian, 2005). The threat of substitutes is high weight and the distribution of these can obtain market share (Peng, 2010).

Resource-based considerations as part of the analysis, allow these considerations examined from several points taken as the framework VRIO, the object of analysis. One is the value of diversification which increases yields and permanence of a company in the market, compared to companies that do not (Peng, 2010). The value is also created by the acquisitions to acquire a resource with market value.

Another important point in the resource analysis is the rarity must have in the market or it must have something particular in the market so it can carry out the acquisition or diversification (Peng, 2010). Imitation: This is a very important point as from it depends on company profits. According to Peng (2010) integration is the increased capacity for imitation difficult because few companies can be integrated after the acquisition. 


\section{Al Macrothink}

World Journal of Business and Management

ISSN 2377-4622

2015, Vol. 1, No. 2

Having an acquisition of an organization, it must take a central command that is making a corporate culture. The analysis continues observing businesses by institutional questions. Peng (2010) distinguishes two types of formal institutions that are focused on emerging economies to provide protectionism of local businesses. This type of protectionism is the cause that makes transnational corporations to exert pressure on governments to decrease protectionism and to enter the market.

\section{Background}

Model group began its work by opening the Cervecería Modelo SA in 1925. Later renamed as currently known as Grupo Modelo in 1991, following growth strategies led it today to have 8 plants in the country with a production capacity of 70 million hectoliters per year spread over 12 brands, exporting to over 180 countries around the world in addition to distributing the brands produced by Anheuser-Busch.

\subsection{Diversification of Products Related}

Model group began to diversify its products importing beers primarily from United States by the company ABI. Later, it imported beer from China, Denmark and Spain. These alliances allowed Grupo Modelo to enter other markets which preferred foreign beers.

\subsection{Diversification Unrelated Products}

The non-related Grupo Modelo products were first the Extra shops, which were not directly engaged in the production of beer but the marketing of beer and snack products mainly. Another product that blew a market that was growing was the bottled water by alliance with Nestlé, which created the company Waters Partners Mexico, who marketing, and sales water Nestlé Pureza Vital, mineral water and products of S. Pellegino group. They are slightly carbonated water. In this partnership, both firms are combining resources made to reduce the risk and use the cheapest resources of both companies.

\subsection{Geographic Diversification}

Grupo Modelo has achieved an extensive international geographic diversification which has a reach of 180 countries around the world and received awards in countries where it is marketed. For example in 2011 in the US, it took third in Premium Beers and won the award Hot Brands for the second time. In Europe, Australia and Latin America there was introduction of new brands such as Victoria, Pacífico, Negra Modelo and Modelo Light that had great acceptance and was sales growth up to $10 \%$ over the previous year of its introduction (Figure 1). 


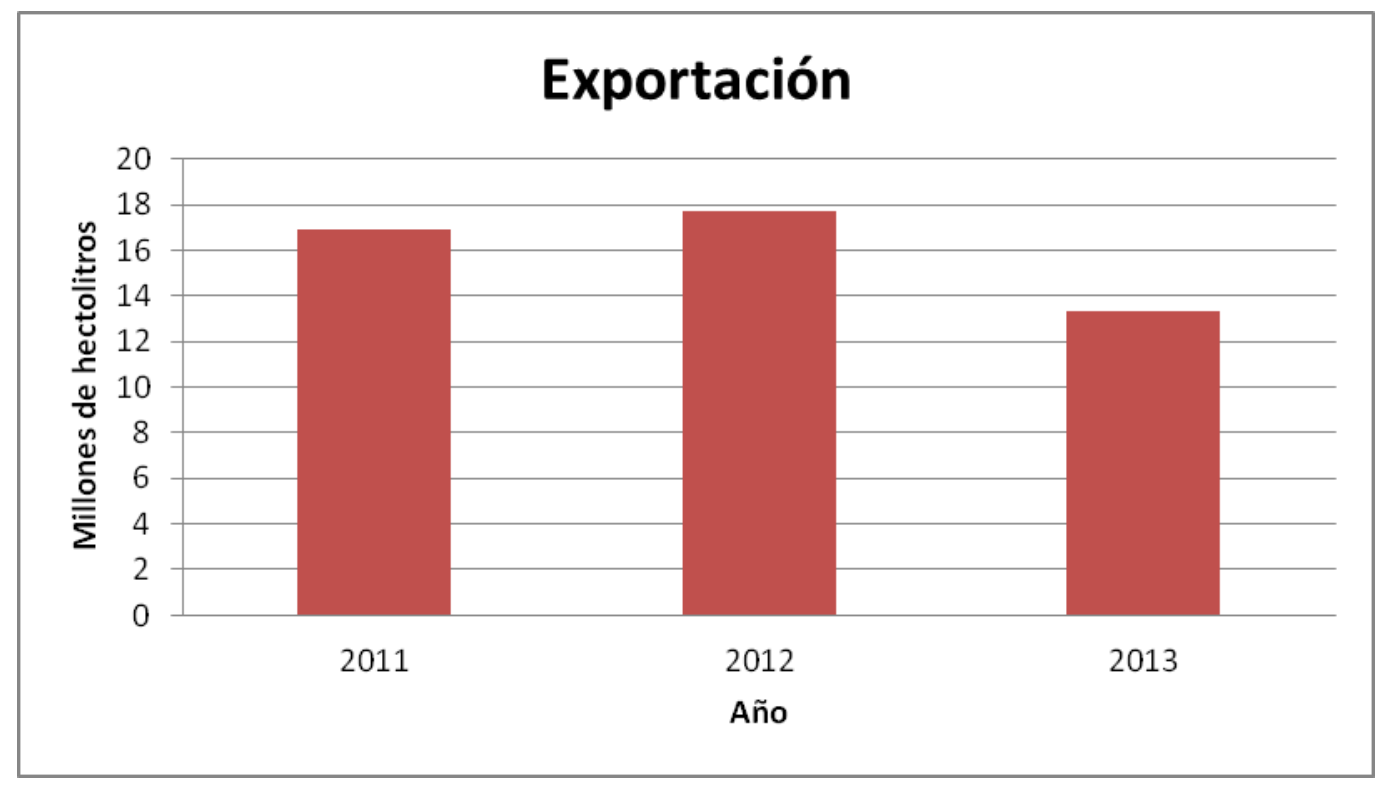

Figure 1. Volume of exports 2011-2013

Source: Based on data from Annual Report of Grupo Modelo (Modelo Annual Report, 2013), published in the Mexican Stock Exchange 2015.

The reduction in sales in 2013 was due to Grupo Modelo as part of the acquisition of ABI, no longer exports to the US by selling the plant in Piedras Negras, Coahuila. This plant has the main function to export to USA.

\subsection{Diversification and Scope of Grupo Modelo}

Grupo Modelo can be classified among the diversification of related products and not related by its expansion strategy in growth markets and further differentiated in markets where already a presence of products had. The above led it to achieve higher profits to 29,000 million pesos. Its geographical expansion is another focal point because the brand is located in more than 180 countries worldwide.

\section{Fundamentals of Peng Tripod}

The industry-based foundations are made within a framework of analysis to support if companies are likely to be acquired or not. In this section is intended to analyze the theory based on the industry.

The beer industry in Mexico has been contracted by the economy because the volume of beer sold has decreased. In the case of Model Group fell by $0.3 \%$ in 2012 and compensated with a price increase of domestic sales which increased by $7.3 \%$. One of the advantages of production in Mexico was reflected in the price weakness against the dollar since the inputs are purchased in dollars and the sale of finished beer is made in dollars. 


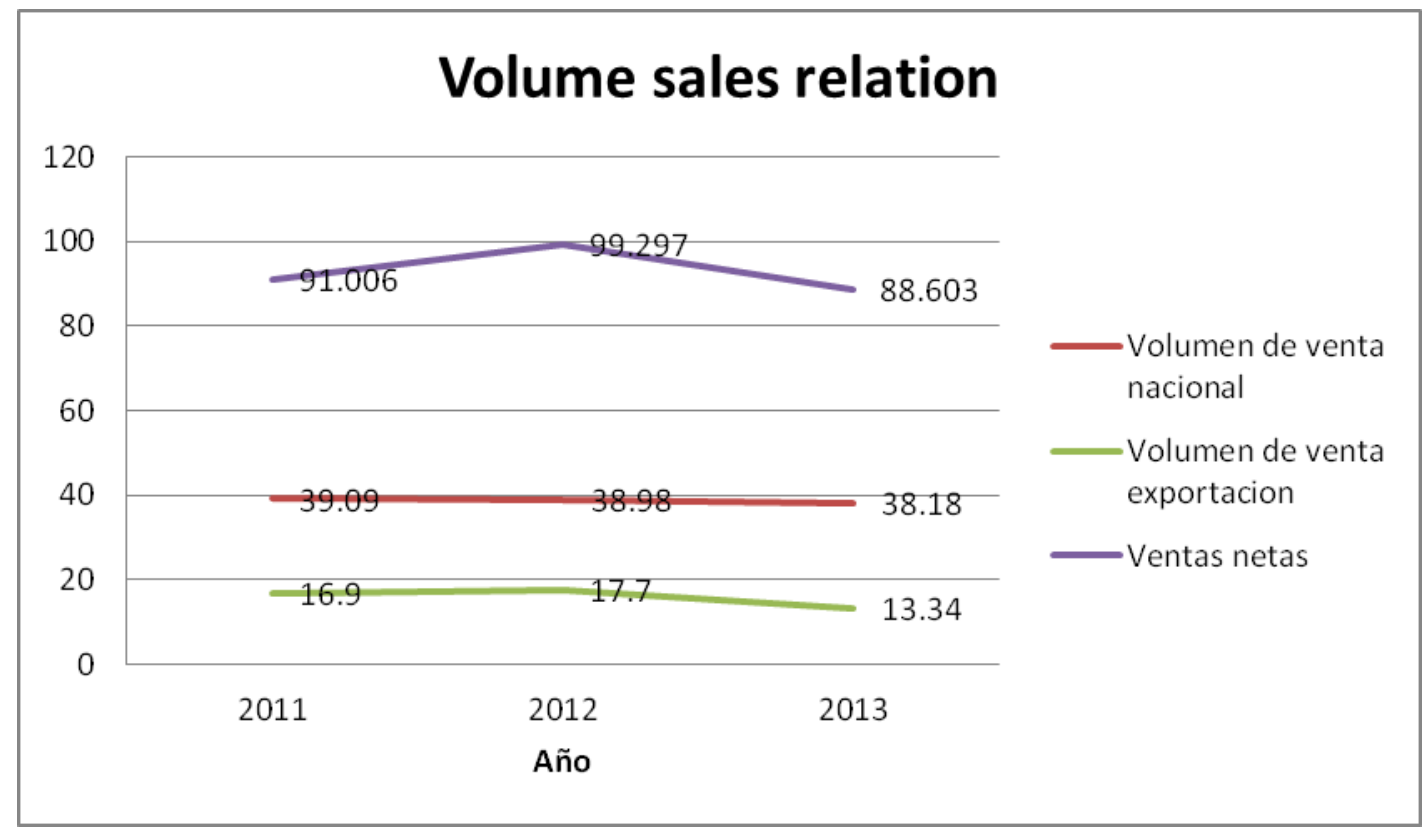

Figure 2. Relationship between volume of sales vs sales

Source: Based on data from annual report of Grupo Modelo (Modelo Annual Report, 2013), published in the Mexican Stock Exchange 2015.

Sales volume is shown in million hectoliters while sales are presented in billions of pesos.

In the chart above you can see that while decrease the volume sold in the domestic market, increased in volume sales abroad. Moreover the factors that influenced the increase net sales were, price increases and a weaker peso. Model Group sales reached historical 99.297 million pesos. Yet sales volume has decreased by $2.3 \%$ in the period 2011-2013, and although some macroeconomic aspects have benefited, it will be not always

\subsection{Rivalry and New Competitors}

It has been marked the rivalry between the two largest brewers in Mexico, which is seen by the market share; since 58\% of the market belongs to Grupo Modelo while $42 \%$ belongs to Cuauhtemoc Moctezuma (Palleres \& Maldonado, 2014). These figures are rounded as a percentage belongs to microbrews. An incoming company called SAB Miller, who believes strongly to penetrate the Mexican market which has extensive barriers to entry. Recall that the company Cuauhtemoc Moctezuma FEMSA which belonged to exchange 100 percent of the shares for a stake of $20 \%$ in Heineken one of the largest producers of beer worldwide. This event was the subject of bringing home a world competitor.

The opening is made to the non-exclusivity of the dominant companies in Mexico. It will be seen further on considerations based on institutional. It opens an opportunity for companies producing craft beer in 2013 as craft beer represented $0.05 \%$ of the national market and according to some analysts, it could reach up to 3 or $5 \%$ in the coming years. Therefore, there is the arrival of serious competitors like The Beer Company dedicated to the distribution and 
sale of craft beer in 2010 who happened to have annual revenue of 1,300,000 to $28,000,000$ pesos in 2013 (Arteaga, 2013).

\subsection{Advantage in Costs and Product Diversification as Part of the Rivalry between Firms}

One of the possible advantages of domestic production of beer is the acquisition of inputs by a vertical integration of the subsidiaries, while ensuring the supply of inputs for production of beer, among the companies that have agreements are: malting mills, plastic caps, cans, cardboard, pot and machinery. To cope with the new rules of non-exclusivity, Grupo Modelo launched the Ideal Model Brew called in their presentations of "Azabache" and "As de Oros". The firm thinks that with these presentations, it will cope with the new demand that is beginning to be present in the market.

\subsection{Bargaining Power with Suppliers and Buyers}

There is bargaining power toward suppliers to have vertical integration which guarantees Grupo Modelo obtaining sufficient supplies over time. As part of the bargaining power towards buyers, it is the exclusive contract which allows Grupo Modelo to have sufficient tools to increase the price without leaving a loss at the end of the year.

\subsection{Substitutes}

Substitute for beer produced in large quantities is the craft beer, although is still far from being a competitor, since according to statistics provided by Forbes; it has not reached even $1 \%$. But it seems promising to have withdrawn exclusive rights by the two largest brewers in Mexico.

\subsection{Barriers to Entry}

One of the barriers to entry for domestic and foreign producers is investment, equipment investment or expansion of production facilities. It is the case of Grupo Modelo who makes an investment in 2011 for 4,151 million pesos, the Mexican currency, of which 654 million was allocated to expand the capacity of the plant in Piedras Negras in Coahuila 5.0 million hectoliters. In 2012 an investment of 5.425 million pesos was made in increasing the production capacity of the plant in Zacatecas. In 2013 was made an investment of 3.343 million pesos. This investment was to optimize the production takes place. In the past three years Model Group has invested 12,919 million pesos which makes that the doors are closed to small producers who cannot invest such a large amount.

Another barrier imposed by the brewing groups is the exclusive contract which contained a single exclusive distributor of beer companies Grupo Modelo or Cuauhtémoc Moctezuma. These exclusive agreements were a sign to sell beer from a single vendor without giving way to otherwise it were sold.

\subsection{Theoretical Framework}

\subsubsection{VRIO Framework}

The framework VRIO allows some considerations based on the resources, whether tangible or 
intangible (Peng, 2010). The value of the company has been its diversification and that over time has increased to 11 brands and marks to cover several markets. Import 6 beer brands which are among the largest in the world. In addition to distributing bottled water and have self-service shops. Another value that can be given to the model group is by the acquisition of the company ABI Model Group, which integrates and diversifies its products.

\subsubsection{Rarity}

The rarity according to Peng is that the company has a special appeal in the market. This special resource makes the acquisition to be looked properly in the eyes of the company that will acquire. The rarity of Grupo Modelo are its managers, because they can take over several important issues, mentioning some non-borrowing, the bargaining power with suppliers because they order nationally for their raw materials that they do not produce e.g. aluminum.

Another important point of rarity in the market for Grupo Modelo is the position that holds a national and international level. It is the company that has greater market control therefore makes it rare.

\subsubsection{Imitation}

The difficult imitation would be given when already acquired the company, but this only happens if it can join an organized way, so senior managers should be "acclimatized" if they cannot acclimate may not make use of the various valuable and rare resources. This section shall state the points of imitation and organization.

After the acquisition of Grupo Modelo there was a restructuring which reduced personnel costs of $11.9 \%$ compared to 2012. Also, it adopted international accounting standards. Before 2013 income tax calculation was made jointly by subsidiaries and Grupo Modelo. Under the new rules by the Ministry of Finance, the income tax calculation is done separately by each of the subsidiaries of Grupo Modelo. Some managers remained in the Grupo Modelo after the acquisition of it, such as Carlos Fernandez Gonzalez who served as CEO of the company, someone who still belongs to the board is Ma. Asuncion Aramburuzabala Larregui who served as vice president of the company.

There is a kind of restructuring but with key personnel within Grupo Modelo, and it is noteworthy that there was a decrease in sales in 2013 but the plant of Piedras Negras Coahuila was also sold, so there is no exact data as decreased sales.

\subsubsection{Institutional Issues}

On institutional issues, it had not been taken consideration by the COFECE, which is the agency responsible for punishing monopolistic practices. Until 2010, the institution conducted an investigation for alleged monopolistic practices of Grupo Modelo and Cuauhtemoc Moctezuma, which concluded that must be respected the existing agreements of exclusiveness until their term of 3-5 years, respectively, and also four important points:

1) A new simpler contract of exclusive is entered.

2) Allow access to Brew to restaurants that already have contracts. 
3) Communicate to customers who have no exclusive contract that the supplier may choose beer more liked.

4) Limit the number of exclusive contracts to no more than $25 \%$ of current sales points reducing that number by 2018 by $20 \%$.

In addition to Article 28 of the Constitution of the United Mexican States exposed the prohibition of monopolies and monopolistic practices. The laws and the institute that applies monopolistic practices have been detected by the Grupo Corona (Crown Group), but the power of large companies seems to be a problem for the institute because it cannot depress their monopoly power. As it can be seen there are still barriers to entry, which the institutions have been identified and has only eased the rules of the game.

Another regulation that increases the price of beer and that means an important component is taxes. For example the IEPS (STPS Special Tax on Production of Services) that is $26.5 \%$ of the sales price of beer. This tax increased from 25 to $26.5 \%$ and it was approved in 2010 . Moreover, at the end of 2009 an increase in VAT from 15 to 16\% was approved. Therefore $46.7 \%$ of sales taxes represent taxes, which mean that a price increase by the institutions was created. This will transfer consequences for small producers because they cannot internalize the costs and these are high for small investments in production.

\section{Conclusion}

The market power that Grupo Modelo had before the acquisition was very large because it was achieved a diversification of products related and not related to in domestic and imported products and domestic and foreign partnerships, apart from exporting and developing international networks of large value in product distribution of Grupo Modelo. This means a high value for companies that would set eyes on the acquisition of this group. But then there was a reduction in sales volume in the global and domestic market. There are factors that led to an increase in prices by taxes which are a determinant of sales price. Price increases helped to achieve record net sales. Moreover the economy reduced growth; this would have led to a decrease in net sales by $2.3 \%$. But this situation cannot occur again because the increase in prices results in a reduction in sales volume (Varian, 1999).

On the other hand there are serious rivals in the domestic market and others seeking to enter. One of which is Heineken that acquired the company Cuauhtemoc Moctezuma, and Miller today seek to have greater market share. On the other hand the institutional issues and companies in the market have fixed barriers, which are declining for the passage of craft beer companies.

These situations paid to have enough evidence to say that Grupo Corona (Crown Group) was losing market and also facing transnational corporations that threatened to enter the market. The COFECE also enabled national companies to have entered the market brew debilitating contracts on exclusivity, although COFECE has not removed all barriers for companies like Miller to enter directly to the market. A short while to open international markets and companies divide the market. 


\section{Macrothink}

World Journal of Business and Management

ISSN 2377-4622

2015, Vol. 1, No. 2

The sale price of the shares by Grupo Modelo was very high and it received an award of 30\% over the closing price of the shares of the $\mathrm{C}$ series in 2012. So it was a good sale regarding previous observations.

\section{References}

Arteaga, R. (2013). Productores van por la "corona" de la cerveza artisanal. Forbes Mexico, negocios. Recuperado el día 15 de mayo del 2015. Retrieved from http://www.forbes.com.mx/productores-van-por-la-corona-de-la-cerveza-artesanal/

Informe anual de Grupo Modelo. (2013). Publicado en la Bolsa Mexicana de Valores. recuperado el día 17 de mayo del 2015. Retrieved from http://www.bmv.com.mx/infoanua/infoanua_524226_2013_1.pdf

North, D. (1990). The Journal of economic Perspectives, 5(1). (Winter, 1991), Published by: American Economic Association.

Palleres, M., \& Maldonado, M. (2014). Duopolio cervecero en México, el más fuerte del mundo. El FINANCIERO, 10 de febrero del 2014. Recuperado el día 18 de mayo del 2015. Retrieved from http://www.elfinanciero.com.mx

Peng, M. (2010). Estrategia global. México: Cangage Learning.

Porter, M. (1980). Competitive Strategy. New York: Free Press.

Tournois, L. (2014). Too many products? Reaching the next billion customers of the beauty market. Journal of Business $\quad$ Strategy, 35 35(5), http://dx.doi.org/10.1108/JBS-12-2013-0119

Varian, H. R. (2005). Microeconomía intermedia: Un enfoque actual (5th ed.). Barcelona: Antoni Bosch.

\section{Copyright Disclaimer}

Copyright for this article is retained by the author(s), with first publication rights granted to the journal.

This is an open-access article distributed under the terms and conditions of the Creative Commons Attribution license (http://creativecommons.org/licenses/by/3.0/). 